\title{
Genetic parameters and breeding values for daily milk production of Holstein cows in terms of heat stress
}

\author{
Goran Vučković ${ }^{1}$, Tina Bobić ${ }^{2 *}$, Pero Mijić ${ }^{2}$, \\ Mirna Gavran², Maja Gregić2 ${ }^{2}$ Klemen Potočnik³ \\ Vladan Bogdanović ${ }^{4}$, Vesna Gantner ${ }^{2}$
}

\footnotetext{
${ }^{1}$ Rinderunion Baden-Württemberg, Herbertingen, Ölkofer Strasse 41, 88518 Herbertingen Germany

${ }^{2}$ University of J. J. Strossmayer in Osijek, Faculty of Agrobiotechnical Sciences Osijek, Department

for animal production and biotechnology Osijek, Vladimira Preloga 1, 31000 Osijek, Croatia

${ }^{3}$ University of Ljubljana, Biotechnical Faculty, Department of Animal Science, Groblje 3, Domžale, Slovenia

${ }^{4}$ University of Belgrade, Faculty of Agriculture, Belgrade, Serbia

${ }^{*}$ Corresponding author: E-mail: tbobic@fazos.hr
}

\section{Abstract}

In order to estimate the variance components as well as the breeding value for daily milk production of Holstein cows in terms of heat stress defined as different THI threshold values (68, 70, and 72) 1,275,713 test-day records from 90,159 cows were used. Temperature-humidity index (THI) calculated from ambient temperature and relative humidity recorded in the barns on the milk recording day was used as the measure of heat stress. Daily milk production was analysed as a bivariate variable, in the normal conditions (under the set $\mathrm{TH} \mathrm{I}_{\text {threshold }}$ value), and in terms of heat stress (above the set $\mathrm{THI}_{\text {threshold }}$ value) using a model that accounted variances due to lactation stage, calving season, age at calving, breeding region, parity, permanent environment, interaction between hear and year, and individual animal. The estimated high genetic correlations between the daily milk production in normal and heat stress conditions, as well as high correlations among the EBVs in normal and heat stress conditions, point out that Holstein cows with high productivity in normal condition will sustain an alike level of production even in terms of heat stress. These results indicate that the Holstein cows are very well acclimatized to the environmental conditions at dairy farms in Croatia. However, these findings should be taken with caution, given that measurements of microclimate parameters were conducted only once at a milk recording day, so the reliability of such measurements could be questionable. In conclusion, in order to realize a completely unambiguous conclusion, further studies that include multiple daily measurements of microclimatic parameters in the farms facilities are necessary.

Key words: daily milk production, heat stress, genetic parameters, Holstein 


\section{Introduction}

Nowadays dairy cattle farms are faced with number of challenges that hinder their active participation in sustainable agricultural and rural development in the European countries. One of the recently more and more pronounced challenge is deterioration of environmental conditions highly correlated to the occurring changes of climate worldwide. These changes frequently lead to adverse (micro)climate on dairy cattle farms and to exposure of animals to heat stress. Heat stress conditions in dairy cows results in the reduction of dry matter intake, milk production and reproductive performances (West et al., 1999; Casa and Ravelo, 2003; Gantner et al., 2011; Bohmanova et al., 2007; Ravagnolo et al., 2000) as well as in changes in the milk composition, somatic cell counts (SCC) and mastitis prevalence (Boura oui et al., 2002; Collier et al., 2012; Correa-Calderon et al., 2004; Gantner et al., 2011, 2017; Ravagnolo et al., 2000; St-Pierre et al., 2003; West, 2003; Hammami et al., 2013; Smith et al., 2013). All of the above mentioned finally results in considerable loss of dairy farm profit (St-Pierre et al., 2003). The threshold value, a point at which ambient temperatures exceed an animal's thermoneutral zone and animal's performance start to decrease depends on the breed, the breeding region, the lactation stage and parity, the production level, as well as on animal's individual capability to manage a stressful environment (Bohmanova et al., 2007; Gantner et al., 2011, 2017). For instance, previous researches reported the temperature-humidity index value - THI (index that combines ambient temperature and relative humidity) of environment in interval from 68 to 72 results in deterioration of productive and reproductive performances of dairy cattle (Ravagnolo et al., 2000; Bouraoui et al., 2002; Casa and Ravelo, 2003; Freitas et al., 2006; Bohmanova et al., 2007; Bernabucci et al., 2010; Collier and Hall, 2012; Hammami et al., 2013; Smith et al., 2013; Lambertz et al., 2014; Gantner et al., 2017). Furthermore, the intensive genetic selection of dairy cattle aiming to increase the milk production shifted the animal's thermoneutrality to lower temperatures (Kadzere et al., 2002; Bohmanova, 2006; Collier et al., 2006). Since changes of climate became our reality, Segnalini et al. (2013) emphasized the necessity of developing strategies to alleviate their impact on livestock production especially in highly intensive production systems. The methods for reduction of the heat stress effect on dairy cows could be classified as short-term and long-term ones. Short-term methods imply farm management optimisation (feeding adjustment and farm's cooling systems), while longterm methods mean the selection of dairy cattle that are more resistant to heat stress environment. Due to the antagonism between heat tolerance and productivity, it is very challenging to implement the selection for heat resistance. It is inevitable to identify the heat tolerant phenotypes and to develop selection methods and statistical models that combine the entire knowledge to achieve the desired goals. Thermo-neutral threshold and drops in milk production were commonly used in many previous types of research. For example, Ravagnolo et al. (2000) used a broken line model to describe genetic components of the reaction to heat stress. Aguilar et al. (2009) used the test-day models that included a random regression on a function of the temperature-humidity index. Brügemann et al. (2011) and Carabano et al. (2014) used polynomials of a second or third order in order to describe the norm of reaction of milk production across the heat load scale. Furthermore, the determination of adequate criteria for the selection for each evaluation model is extremely important. In the broken line model, as selection criteria, both the thermotolerance threshold and the slope of animal's response could be used. On the other hand, in the case of higher-order polynomials used to describe the animal's reaction to heat stress, the slope of the individual polynomial curve under moderate or severe heat stress could be used as criteria for selection (Carabaño et al., 2014). In order to apply long-term mitigation method that is simple from a practical point of view this research aimed to estimate variance components as well as breeding value for daily milk production of Holstein cows in terms of heat stress defined as different THI threshold values $(68,70$, and 72). Daily milk production was analysed as a bivariate variable in normal conditions (under the set $\mathrm{THI}_{\text {threshold }}$ value) and in terms of heat stress (above the set $\mathrm{THI}$ threshold value). 


\section{Material and methods}

Test-day records of Holstein cows collected during the regular milk recording in the period from January 2005 to December 2013 were provided by the Croatian Agricultural Agency. At each milk recording, measuring and sampling of milk were performed during the evening or morning milkings (AT4 or BT4 method). Furthermore, at each recording, ambient temperature and relative humidity in the barns were recorded. Test-day records with lactation stage in ( $<5$ days and $>400$ days), age at first calving in ( $<21$ and $>36$ months), missing parity, missing breed, missing or nonsense daily milk traits (accordingly to ICAR standards, 2017), and missing or nonsense $\mathrm{Ta}$ and $\mathrm{RH}$ value were deleted from the dataset. After logical control dataset consisted of 1.275,713 test-day records from 90.159 Holsteins reared on 6.701 farms. Accordingly, to the parity, cows were divided into seven classes: 1., ..., 7. (animals in seventh and higher lactations). Furthermore, according to the location of the farm, testday records were divided into 16 breeding regions. In accordance to the calving date, test-day records were divided into four recording seasons: spring (March, April, and May), summer (June, July, and August) autumn (September, October, and November), and winter (December, January, and February). Based on the measured microclimate parameters, the temperature-humidity index (THI) was calculated using the equation by Kibler (1964):

$$
\mathrm{THI}=1.8 \times \mathrm{Ta}-(1-\mathrm{RH}) \times(\mathrm{Ta}-14.3)+32
$$

where Ta presents the average temperature in degrees Celsius while $\mathrm{RH}$ is the relative humidity as a fraction of the unit.

A function ( $f$ ) of $\mathrm{THI}$ was created as follows:

$$
f(T H I)= \begin{cases}0 & \text { if } T H I \leq T H I_{\text {threshold }} \\ 1 & \text { if } T H I>T H I_{\text {threshold }}\end{cases}
$$

where $\mathrm{THI}$ threshold was set to 68,70 , and 72 .

For the estimation of variance components and breeding values of the daily milk production of Holstein cows in terms of heat stress following bivariate model was used:

$$
\begin{gathered}
\mathrm{y}_{\mathrm{ijk} \mid m n o p}=\mu+\mathrm{b}_{1}\left(\mathrm{~d}_{\mathrm{i}} / 305\right)+\mathrm{b}_{2}\left(\mathrm{~d}_{\mathrm{i}} / 305\right)^{2}+\mathrm{b}_{3} \ln \left(305 / \mathrm{d}_{\mathrm{i}}\right)+\mathrm{b}_{4} \ln ^{2}\left(305 / \mathrm{d}_{\mathrm{i}}\right)+\mathrm{S}_{\mathrm{j}}+\mathrm{b}_{5} \mathrm{ac}_{\mathrm{k}}+\mathrm{b}_{6} \mathrm{ac}_{\mathrm{k}}^{2}+ \\
\mathrm{R}_{1}+\mathrm{P}_{\mathrm{im}}+\mathrm{Pe}_{\mathrm{n}}+\mathrm{Hy}_{\mathrm{o}}+\mathrm{a}_{\mathrm{p}}+\mathrm{e}_{\mathrm{ijk} \mathrm{kmnop}}
\end{gathered}
$$

where $\mathrm{y}_{\mathrm{ijk} k \mathrm{mnop}}=$ estimated daily milk production at $\mathrm{THI}=0$ and $\mathrm{THI}=1$;

$\mu=$ intercept;

$\mathrm{b}_{1}, \mathrm{~b}_{2}, \mathrm{~b}_{3}, \mathrm{~b}_{4}, \mathrm{~b}_{5}, \mathrm{~b}_{6}=$ regression coefficients;

$\mathrm{d}_{\mathrm{i}}=$ days in milk ( $\mathrm{i}=5, \ldots, 400$ day);

$S_{i}=$ fixed effect of calving season class $j(j=1 / 2005,2 / 2005, \ldots, 4 / 2012)$;

$\mathrm{ac}_{\mathrm{k}}=$ fixed effect of age at calving as square regression;

$R_{1}=$ fixed effect of breeding region $I(I=01, \ldots, 16)$;

$P_{\text {im }}=$ fixed effect of parity $m(m=01, \ldots, 07$; nested within the lactation curve);

$\mathrm{Pe}_{\mathrm{n}}$ - random permanent environmental effect for the cow;

$\mathrm{Hy}_{0}$ - random effect of interaction between hear and year;

$a_{p}$ - random additive genetic effect for the cow;

$\mathrm{e}_{\mathrm{ijklmnop}}=$ random residual effect.

For the preparation and logical control of data SAS/STAT (SAS Institute Inc., 2000) was used. For estimation of variance components for milk production of dairy cows VCE-6, version 6.0.3-dev (Kovač et al., 2012) was used. Furthermore, breeding values of Holstein cows in terms of heat stress defined as different values of THI threshold values $(68,70$, and 72 ) were estimated using the same software. 


\section{Results and discussion}

In this study, the animal's reaction to heat stress environment was analysed using the bivariate model where the daily milk production in the normal conditions $(\mathrm{THI}=0$ ) was taken as the first variable while the daily milk production in the environment characterised by heat stress $(\mathrm{THI}=1)$ was taken as the second one. The estimated variance components for daily milk production in regard to the set threshold values ( $\mathrm{THI}$ threshold in 68,70 or 72 ) are presented in Table 1. The variance for the permanent environment when $\mathrm{THI}=0$ ranged from $11.386 \mathrm{~kg}^{2}$ to $11.641 \mathrm{~kg}^{2}$, while for $\mathrm{THI}=1$ ranged from 11.190 $\mathrm{kg}^{2}$ to $11.841 \mathrm{~kg}^{2}$ depending on set $\mathrm{TH} \mathrm{threshold}_{\text {value. }}$ Obtained results indicate that at higher $\mathrm{THI}$ values the effect of the permanent environment was more prominent. The variance for the herd-year interaction also increased as the $\mathrm{THI}{ }_{\text {threshold }}$ value increased, with higher variance values determined in terms of heats stress $(\mathrm{THI}=1)$. On contrary, the estimated variance for the animal decreased with increase of $\mathrm{THI}$ threshold value, with lower variance values determined in heat stress conditions.

Similarly, Aguilar et al. (2009) determined that the evaluated additive genetic variance for milk, fat, and protein yields highly depends on THI value, stage of lactation, parity, and statistical model used for the evaluation. Aguilar et al. (2009) ascertained that the function of total additive genetic variance and THI had a typical quadratic shape, which corresponded to findings of Ravagnolo and Misztal (2000). Moreover, the genetic variance for heat tolerance significantly enlarged at the end of lactation and in higher parities. The effect of lactation stage on the additive genetic variance among the highest values defined at the end of lactation (DIM in 300) was also recognized by Brugemann et al. (2011). Same authors determined the reduction of additive genetic variance and permanent environment variance for test-day protein yield in terms of increasing $\mathrm{THI}$ value that is from 21 to 72 .

TABLE 1. Estimated variances and covariance for daily milk production of Holstein cows in regard to set threshold values (THI threshold in 68,70 , or 72 )

\begin{tabular}{l|l|l|l}
\hline Effect & Variance (THI - 0) & Variance $($ THI - 1) & Covariance \\
\hline THI $_{\text {threshold }}$ in 68 (DMY 48.28 vs 45.33) & \multicolumn{3}{|l}{} \\
\hline Penv & $11.6407 \pm 0.08523 \mathrm{~kg}^{2}$ & $11.1895 \pm 0.11864 \mathrm{~kg}^{2}$ & $9.7591 \pm 0.08779 \mathrm{~kg}^{2}$ \\
\hline Hyear & $8.27282 \pm 0.15181 \mathrm{~kg}^{2}$ & $9.71132 \pm 0.19553 \mathrm{~kg}^{2}$ & $8.11141 \pm 0.15721 \mathrm{~kg}^{2}$ \\
\hline Animal & $9.80707 \pm 0.13229 \mathrm{~kg}^{2}$ & $9.20131 \pm 0.15652 \mathrm{~kg}^{2}$ & $8.96254 \pm 0.12544 \mathrm{~kg}^{2}$ \\
\hline Residual & $18.5586 \pm 0.030809 \mathrm{~kg}^{2}$ & $15.2324 \pm 0.058844 \mathrm{~kg}^{2}$ & - \\
\hline THI ${ }_{\text {trreshold }}$ in 70 (DMY $\left.48.27 \mathrm{vs} 44.79\right)$ & & \\
\hline Penv & $11.5145 \pm 0.08552 \mathrm{~kg}^{2}$ & $11.3893 \pm 0.13122 \mathrm{~kg}^{2}$ & $9.7225 \pm 0.08825 \mathrm{~kg}^{2}$ \\
\hline Hyear & $8.31285 \pm 0.15667 \mathrm{~kg}^{2}$ & $9.75394 \pm 0.20254 \mathrm{~kg}^{2}$ & $8.14021 \pm 0.16185 \mathrm{~kg}^{2}$ \\
\hline Animal & $9.76130 \pm 0.13339 \mathrm{~kg}^{2}$ & $9.07161 \pm 0.16561 \mathrm{~kg}^{2}$ & $8.91184 \pm 0.12865 \mathrm{~kg}^{2}$ \\
\hline Residual & $18.6856 \pm 0.031694 \mathrm{~kg}^{2}$ & $14.5760 \pm 0.064901 \mathrm{~kg}^{2}$ & - \\
\hline THI ${ }_{\text {threshold }}$ in 72 (DMY $\left.48.23 \mathrm{vs} 44.31\right)$ & & \\
\hline Penv & $11.3858 \pm 0.07841 \mathrm{~kg}^{2}$ & $11.8413 \pm 0.15383 \mathrm{~kg}^{2}$ & $9.7582 \pm 0.09426 \mathrm{~kg}^{2}$ \\
\hline Hyear & $8.34451 \pm 0.15330 \mathrm{~kg}^{2}$ & $9.96719 \pm 0.21632 \mathrm{~kg}^{2}$ & $8.19485 \pm 0.16508 \mathrm{~kg}^{2}$ \\
\hline Animal & $9.71994 \pm 0.13159 \mathrm{~kg}^{2}$ & $8.91724 \pm 0.17880 \mathrm{~kg}^{2}$ & $8.83270 \pm 0.13134 \mathrm{~kg}^{2}$ \\
\hline Residual & $18.7763 \pm 0.032042 \mathrm{~kg}^{2}$ & $13.5879 \pm 0.077664 \mathrm{~kg}^{2}$ & - \\
\hline
\end{tabular}

*Penv - permanent environment; Hyear - herd-year interaction 
TABLE 2. The estimated ratios and correlations for daily milk production of Holstein cows in regard to set threshold values (THI ${ }_{\text {threshold }}$ in 68, 70, or 72)

\begin{tabular}{l|l|l|l}
\hline Effect & Ratio (THI - 0) & Ratio (THI - 1) & Correlation \\
\hline THI $_{\text {threshold }}$ in 68 & $0.24111 \pm 0.1866 \mathrm{E}-02$ & $0.24682 \pm 0.2668 \mathrm{E}-02$ & $0.85509 \pm 0.3966 \mathrm{E}-02$ \\
\hline Penv & $0.17135 \pm 0.2744 \mathrm{E}-02$ & $0.21421 \pm 0.3544 \mathrm{E}-02$ & $0.90496 \pm 0.3784 \mathrm{E}-02$ \\
\hline Hyear & $0.20313 \pm 0.2565 \mathrm{E}-02$ & $0.20296 \pm 0.3276 \mathrm{E}-02$ & $0.94349 \pm 0.4040 \mathrm{E}-02$ \\
\hline Animal & $0.38440 \pm 0.1453 \mathrm{E}-02$ & $0.33600 \pm 0.2001 \mathrm{E}-02$ & - \\
\hline Residual & \multicolumn{3}{|l}{} \\
\hline THI $_{\text {threshold }}$ in 70 & $0.23852 \pm 0.1807 \mathrm{E}-02$ & $0.25428 \pm 0.2957 \mathrm{E}-02$ & $0.84900 \pm 0.4218 \mathrm{E}-02$ \\
\hline Penv & $0.17220 \pm 0.2816 \mathrm{E}-02$ & $0.21777 \pm 0.3715 \mathrm{E}-02$ & $0.90401 \pm 0.3827 \mathrm{E}-02$ \\
\hline Hyear & $0.20220 \pm 0.2624 \mathrm{E}-02$ & $0.20253 \pm 0.3525 \mathrm{E}-02$ & $0.94705 \pm 0.4411 \mathrm{E}-02$ \\
\hline Animal & $0.38707 \pm 0.1508 \mathrm{E}-02$ & $0.32542 \pm 0.2163 \mathrm{E}-02$ & - \\
\hline Residual & \multicolumn{3}{|l|}{} \\
\hline THI ${ }_{\text {threshold }}$ in 72 & $0.23609 \pm 0.1736 \mathrm{E}-02$ & $0.26722 \pm 0.3485 \mathrm{E}-02$ & $0.84040 \pm 0.4581 \mathrm{E}-02$ \\
\hline Penv & $0.17303 \pm 0.2755 \mathrm{E}-02$ & $0.22492 \pm 0.4003 \mathrm{E}-02$ & $0.89858 \pm 0.4381 \mathrm{E}-02$ \\
\hline Hyear & $0.20155 \pm 0.2547 \mathrm{E}-02$ & $0.20123 \pm 0.3853 \mathrm{E}-02$ & $0.94874 \pm 0.5090 \mathrm{E}-02$ \\
\hline Animal & $0.38934 \pm 0.1503 \mathrm{E}-02$ & $0.30663 \pm 0.2326 \mathrm{E}-02$ & - \\
\hline Residual & &
\end{tabular}

*Penv - permanent environment; Hyear - herd-year interaction

The estimated variance ratios and correlations for daily milk production of Holstein cows in regard to set threshold values (THI threshold in 68, 70 or 72 ) are shown in Table 2 . Variability of the daily milk production due to the permanent environment ranged from 23.61 to $26.72 \%$ depending on environmental characteristics. The effect of the permanent environment was most pronounced in the barns with $\mathrm{THI}$ values higher than 72 . The amount of variability of daily milk production due to herd-year interaction ranged between $17.14 \%$ $22.5 \%$ with the highest proportion of variability determined in an environment characterized by heat stress and at highest THI threshold value. Lastly, heritability for daily milk production in normal conditions $(\mathrm{THI}=0$ ) ranged between $20.16 \%-20.31$ $\%$. The determined values of heritability in terms of heat stress $(\mathrm{THI}=1)$ were similar and ranged between 20.12 and $20.30 \%$. The obtained results indicate a very important role of herd management in mitigation of heat stress on dairy farms. The estimated genetic correlations were high and differed, depending on THI threshold value, from $94.35 \%$ at the lowest THI (68) to $94.87 \%$ at the highest analysed THI (72) value. High values of estimated genetic correlations between the daily milk production in normal conditions and the daily milk production in conditions defined by heat stress signify that cows with high performance in normal conditions will maintain alike production levels also in terms of heat stress.

Sanchez et al. (2009) defined comparatively constant values of heritability for daily milk production as a function of THI (ranged from 60 to 90). Aguilar et al. (2009) stated that the values of heritability for milk yield depend on lactation stage, parity and THI value including the highest values at the end of lactation, and in third parity, with insignificantly increase at higher THIs. Ravagnolo and Misztal (2000) defined a slight increase of heritability for protein yield as well as a piddling reduction of heritability for fat yield with increasing THI from 
TABLE 3. Basic statistics of estimated breeding values (EBV) for daily milk production of Holstein cows in regard to set threshold values (THI threshold in 68,70 , or 72 )

\begin{tabular}{|c|c|c|c|c|c|c|c|c|c|c|c|}
\hline \multirow[t]{2}{*}{ THI } & \multicolumn{5}{|c|}{ EBV $(\mathrm{THI}-0)$} & \multicolumn{5}{|c|}{ EBV $(\mathrm{THI}-1)$} & \multirow[t]{2}{*}{$r$} \\
\hline & mean & SD & $\mathrm{CV}$ & MIN & MAX & mean & SD & $\mathrm{CV}$ & MIN & MAX & \\
\hline 68 & 100.675 & 14.30 & 14.21 & 52.028 & 147.961 & 100.672 & 14.30 & 14.20 & 52.030 & 147.957 & 0.98642 \\
\hline 70 & 100.679 & 14.30 & 14.21 & 52.028 & 147.960 & 100.620 & 14.30 & 14.22 & 52.029 & 147.955 & 0.98819 \\
\hline 72 & 100.670 & 14.31 & 14.21 & 52.028 & 147.960 & 100.693 & 14.29 & 14.19 & 52.028 & 147.958 & 0.98908 \\
\hline
\end{tabular}

${ }^{*} r$ - correlation between the EBV in normal (THI - 0) and heat stress environment (THI - 1); all correlation coefficients were statistically highly significant $(p<0.001)$

72 to 85 . On contrary, Brugemann et al. (2011) concluded that the values of heritability for protein yield were highest at lower THI values (but with $\mathrm{THI}$ in interval 21-72) and at the end of lactation. The same authors indicated that the impact of the lactation stage on heritability values was more noticeable than the effect of THI. Aguilar et al. (2009) advised that the genetic correlations between parities for the effect of heat tolerance varied from 0.56 to 0.79 indicated variations in heat tolerance due to parity.

Basic statistics of the estimated breeding values (EBV) for daily milk production of Holstein cows in normal and heat stress environment in regard to set threshold values ( $\mathrm{THI}_{\text {threshold }}$ in 68,70 , or 72 ) is presented in Table 3. The mean values of EBVs, despite the environmental conditions, amounted to approximately 100.6. Additionally, the mean value of EBVs for daily milk production in normal conditions was the highest at the mean THI value (70), while in heat stress condition the highest EBVs were at the highest THI value (72). The correlations within the EBVs in normal and heat stress conditions was high and differed between 98.64-98.91\% showing a great bond between cow's productivity in normal and heat stress environment.

Aguilar et al. (2009) in the study of genetic elements of heat stress for dairy cattle concluded that the value of genetic variance for heat tolerance for milk yield depends on the applied model (random regression vs repeatability model). For the analysis of variance components of response to heat stress Ravagnolo et al. (2000) applied the so-called broken line model that is characterized by the thermoneutrality threshold and the slope of production decrease after the determined threshold. Moreover, in some studies (Brügemann et al., 2011; Menendez-Buxadera et al., 2012; Carabaño et al., 2014) the variation in the day milk production in terms of heat stress was defined as polynomial functions that permit more flexible approach than the broken line models. Accordingly, to Gaughan et al. (2012) one of the principal obstacles in the application of any evaluation model is way of combination of micro/climate variables. Carabaño et al. (2014) emphasized the importance of defining the proper period between the test-day and the date when measurements of micro/climate occurred. Also, it is extremely important to define the proper selection criteria for every evaluation model. In the broken line model, as selection criteria, both the thermotolerance threshold and the incline of the animal's response could be applied. Carabaño et al. (2014) stated that in the example of higher-order polynomials used to represent the animal's response to heat stress as criteria for selection, the slope of the particular polynomial curve under moderate or severe heat stress could be used. Sánchez et al. (2009) emphasized that the application of the model in practice will indicate the animals with higher adaptation capabilities that is those cows who have lower decrease in production as well as a later reaction on environmental stress). Besides, Carabaño et al. (2014) stated the variability in genetic response and the re-ranking of animals thus to various temperatures pointing out some interaction between the genotype and (micro)climate. Aiming to simplification of practical 
selection of animals for resistance to heat stress in this study, the daily milk production was analysed as a bivariate variable in the normal conditions (under the set $\mathrm{THI}_{\text {threshold }}$ value), and in terms of heat stress (above the set $\mathrm{THI}_{\text {threshold }}$ value). The estimated high genetic correlations between the daily milk production in normal and heat stress conditions, as well as high correlations among the EBVs in normal and heat stress conditions, point out that Holstein cows with high productivity in normal condition will sustain an alike level of production even in terms of heat stress. Given the obtained results, good acclimatization of Holstein cows to environmental conditions on dairy cattle farms could be assumed.

\section{Conclusions}

The results obtained in this study point to the fact that the Holstein cows are very well acclimatized to the environmental conditions at dairy farms in Croatia. However, the results should be taken with caution, given that measurements of microclimate parameters were conducted only once at a milk recording day, so the reliability of such measurements could be questionable. In conclusion, in order to realise a completely unambiguous conclusion, further studies that include multiple daily measurements of microclimatic parameters in the farms facilities are necessary.

\section{Genetski parametri i uzgojne vrijednosti za dnevnu proizvodnju mlijeka holstein krava u uvjetima toplinskog stresa}

\section{Sažetak}

Prilikom procjene komponenti varijance te uzgojnih vrijednosti za dnevnu proizvodnju mlijeka krava holstein pasmine u uvjetima toplinskog stresa koji je definiran pri različitim graničnim vrijednostima THI-a $(68,70$, i 72) korišteno je ukupno 1.275,713 zapisa na kontrolni dan prikupljenih na 90.159 krava. Temperaturno-humidni indeks (THI) koji je izračunat na osnovu izmjerene temperature i relativne vlage u stajama na dan kontrole mliječnosti, korišten je kao mjera toplinskog stresa. Prilikom statističke analize, dnevna proizvodnja mlijeka uvažena je kao bivariatno svojstvo i to u normalnim uvjetima (ispod $\mathrm{THI}_{\text {threshold }}$ vrijednosti) te u uvjetima toplinskog stresa (iznad THI ${ }_{\text {threshold }}$ vrijednosti). Primijenjeni statistički model uvažio je varijabilnost uslijed stadija laktacije, sezone teljenja, dobi pri teljenju, regije uzgoja, pariteta, permanentnog okoliša, interakcije između stada i godine te pojedine životinje. Procijenjene visoke vrijednosti genetske korelacije između dnevne proizvodnje mlijeka u normalnim te u uvjetima toplotnog stresa, kao i vrlo visoke vrijednosti korelacija između procijenjenih uzgojnih vrijednosti za dnevnu proizvodnju mlijeka (EBV) u normalnim i toplinsko stresnim uvjetima indiciraju da će visoko proizvodna grla u normalnim okolišnim uvjetima sličnu razinu proizvodnje održati i u uvjetima toplinskog stresa. Dobiveni rezultati ukazuju na činjenicu da su krave holstein pasmine vrlo dobro aklimatizirane na okolišne uvjete na farmama mliječnih goveda u Hrvatskoj. Međutim, ove rezultate treba uzeti s dozom opreza, obzirom da su mjerenja mikroklimatskih parametara u objektima provođena samo jednom na dan kontrole mliječnosti, tako da pouzdanost tih mjerenja može biti upitna. Zaključno, kako bismo utvrdili potpuno nedvosmislen zaključak, neophodna su daljnja istraživanja u kojima će se provoditi višestruka dnevna mjerenja mikroklimatskih parametara u farmskim objektima.

Ključne riječi: dnevna proizvodnja mlijeka, toplinski stres, genetski parametri, holstein pasmina 
1. Aguilar, I., Misztal, I., Tsuruta, S. (2009): Genetic components of heat stress for dairy cattle with multiple lactations. Journal of Dairy Science 92, 5702-5711. https://doi.org/10.3168/jds.2008-1928.

2. Bernabucci, U., Lacetera, N., Baumgard, L.H., Rhoads, R.P., Ronchi, B., Nardone, A. (2010): Metabolic and hormonal acclimation to heat stress in domestic ruminants. Animal 4, 1167-1183. https://doi.org/10.1017/S175173111000090X

3. Biffani, S., Bernabucci, U., Vitali, A., Lacetera, N., Nardone, A. (2016): Short communication: effect of heat stress on the non-return rate of Italian Holstein cows. Journal of Dairy Science 99, 5837-5843. https://doi.org/10.3168/jds.2015-10491

4. Bohmanova, J. (2006): Studies on genetics of heat stress in US Holsteins. PhD thesis. Athens: University of Georgia.

5. Bohmanova, J., Misztal, I., Cole, J.B. (2007): Temperaturehumidity indices as indicators of milk production losses due to heat stress. Journal of Dairy Science 90, 19471956. https://doi.org/10.3168/jds.2006-513

6. Bouraoui, R., Lahmar, M., Majdoub, A., Djemali, M., Belyea, R. (2002): The relationship of temperature humidity-index with milk production of dairy cows in a Mediterranean climate. Animal Research 51, 479-491. https://doi.org/10.1051/animres:2002036

7. Bradford, H.L., Fragomeni, B.O., Bertrand, J.K., Lourenco D.A.L., Misztal, I. (2016): Genetic evaluations for growth heat tolerance in Angus cattle. Journal of Animal Science 94, 4143-4150. https://doi.org/10.2527/jas.2016-0707

8. Brügemann, K., Gernand, E., von Borstel, U. U., König, S. (2011): Genetic analyses of protein yield in dairy cows applying random regression models with time-dependent and temperature $\mathrm{x}$ humidity-dependent covariates. Journal of Dairy Science 94, 4129-4139. https://doi.org/10.3168/jds.2010-4063

9. Carabaño, M.J., Bachagha, K., Ramón, M., Díaz, C. (2014): Modeling heat stress effect on Holstein cows under hot and dry conditions: Selection tools. Journal of Dairy Science 97, 7889-7904. https://doi.org/10.3168/jds.2014-8023

10. Casa, A.C., Ravelo, A.C. (2003): Assessing temperature and humidity conditions for dairy cattle in Cordoba, Argentina. International Journal of Biometeorology 48, 6-9. https://doi.org/10.1007/s00484-003-0179-x
11. Collier, R.J., Dahl, G.E., van Baale, M.J. (2006): Major advances associated with environmental effects on dairy cattle. Journal of Dairy Science 89, 1244-1253. https://doi.org/10.3168/jds.s0022-0302(06)72193-2

12. Collier, R.J., Hall, L.W. (2012): Quantifying heat stress and its impact on metabolism and performance. Tucson, Arizona: Department of Animal Sciences, University of Arizona.

13. Correa-Calderon, A., Armstrong, D., Ray, D., de Nise, S., Enns, M., Howison, C. (2004): Thermoregulatory responses of Holstein and Brown Swiss heat-stressed dairy cows to two different cooling systems. International Journal of Biometeorology 48, 142-148. https://doi.org/10.1007/s00484-003-0194-y

14. Freitas, M., Misztal, I., Bohmanova, J., Torres, R. (2006): Regional differences in heat stress in U.S. Holsteins. Proc 8th World Congr. Genet. Appl. Livest. Prod., Commun. 01 11, Instituto Prociencia, Belo Horizonte, Brazil.

15. Gantner, V., Mijić, P., Kuterovac, K., Solić, D., Gantner, R. (2011): Temperature-humidity index values and their significance on the daily production of dairy cattle. Mljekarstvo 61 (1), 56-63.

16. Gantner, V., Bobić, T., Gantner, R., Gregić, M., Kuterovac, K., Novaković, J., Potočnik, K. (2017): Differences in response to heat stress due to production level and breed of dairy cows. International Journal of Biometeorology 61, 9; 16751685. https://doi.org/10.1007/s00484-017-1348-7

17. Gaughan, J.B., Mader, T.L., Gebremedhim, K.G. (2012): Rethinking heat index tools for livestock. In: Collier, R.J., and J.L. Collier. Environmental physiology of livestock. Chichester, West Sussex, UK: Wiley-Blackwell. https://doi.org/10.1002/9781119949091.ch14

18. Hammami, H., Bormann, J., M'hamdi, N., Montaldo, H.H., Gengler, N. (2013): Evaluation of heat stress effects on production traits and somatic cell score of Holsteins in a temperate environment. Journal of Dairy Science 96, 1844-1855. https://doi.org/10.3168/jds.2012-5947

19. Hubbard, K.G., Stooksbury, D.E., Hahn, G.L., Mader, T.L. (1999): A climatologic perspective on feedlot cattle performance and mortality related to the temperaturehumidity index. Journal of Production Agriculture 12, 650-653. https://doi.org/10.2134/jpa1999.0650

20. Kadzere, C.T., Murphy, M.R., Silanikove, N., Maltz, E. (2002): Heat stress in lactating dairy cows: a review. Livestock Production Science 77, 59-91. https://doi.org/10.1016/s0301-6226(01)00330-x 
21. Lambertz, C., Sanker, C., Gauly, M. (2014): Climatic effects on milk production traits and somatic cell score in lactating Holstein-Friesian cows in different housing systems. Journal of Dairy Science 97, 319-329. https://doi.org/10.3168/jds.2013-7217

22. Menéndez-Buxadera, A., Molina, A., Arrebola, F., Clemente, I., Serradilla J.M. (2012): Genetic variation of adaptation to heat stress in two Spanish dairy goat breeds. Journal of Animal Breeding and Genetics 129, 306-315. https://doi.org/10.1111/j.1439-0388.2011.00984.x

23. Ravagnolo, O., Misztal, I. (2000): Genetic component of heat stress in dairy cattle, parameter estimation. Journal of Dairy Science 83, 2126-2130. https://doi.org/10.3168/jds.s0022-0302(00)75095-8

24. Sánchez, J. P., Misztal, I., Aguilar, I., Zumbach, B., Rekaya, R. (2009): Genetic determination of the onset of heat stress on daily milk production in the US Holstein cattle. Journal of Dairy Science 92, 4035-4045. https://doi.org/10.3168/jds.2008-1626

25. Segnalini, M., Bernabucci, U., Vitali, A., Nardone, A., Lacetera, N. (2013): Temperature humidity index scenarios in the Mediterranean basin. International Journal of Biometeorology 57, 451-458.

https://doi.org/10.1007/s00484-012-0571-5
26. Smith, D.L., Smith, T., Rude, B.J., Ward, S.H. (2013): Comparison of the effects of heat stress on milk and component yields and somatic cell score in Holstein and Jersey cows. Journal of Dairy Science 96, 3028-3033. https://doi.org/10.3168/jds.2012-5737

27. St-Pierre, N.R., Cobanov, B., Schnitkey, G. (2003): Economic loses from heat stress by US livestock industries. Journal of Dairy Science 86, 52-77. https://doi.org/10.3168/jds.s0022-0302(03)74040-5

28. West, J.W., Hill, G.M., Fernandez, J.M., Mandebvu, P., Mullinix, B.G. (1999): Effect of dietary fiber on intake, milk yield, and digestion by lactating dairy cows during cool or hot, humid weather. Journal of Dairy Science 82, 2455-2465. https://doi.org/10.3168/jds.s0022-0302(99)75497-4

29. West, J.W. (2003): Effects of heat-stress on production in dairy cattle. Journal of Dairy Science 86, 2131-2144. https://doi.org/10.3168/jds.s0022-0302(03)73803-x 